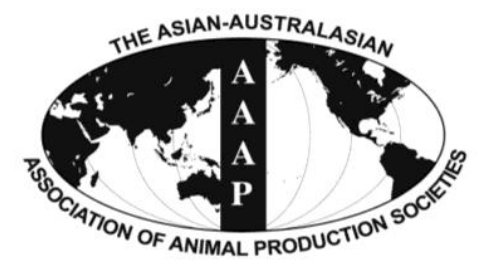

Asian-Aust. J. Anim. Sci.

Vol. 25, No. $3: 325$ - 334

March 2012

www.ajas.info

http://dx.doi.org/10.5713/ajas.2011.11131

\title{
Influence of Rain Tree Pod Meal Supplementation on Rice Straw Based Diets Using In vitro Gas Fermentation Technique
}

\author{
N. Anantasook and M. Wanapat* \\ Tropical Feed Resources Research and Development Center (TROFREC), Department of Animal Science, \\ Faculty of Agriculture, Khon Kaen University, Khon Kaen, 40002, Thailand
}

\begin{abstract}
The objective of this study was to determine the roughage to concentrate (R:C) ratio with rain tree pod meal (RPM) supplementation on in vitro fermentation using gas production technique. The experiment design was a $6 \times 4$ factorial arrangement in a CRD. Factor A was 6 levels of R:C ratio (100:0, 80:20, 60:40, 40:60, 20:80 and 0:100) and factor B was 4 levels of RPM (0, 4, 8 and 12 $\mathrm{mg}$ ). It was found that gas kinetic, extent rate (c) was linearly increased $(\mathrm{p}<0.01)$ with an increasing level of concentrate while cumulative gas production (96 h) was higher in R:C of 40:60. In addition, interaction of R:C ratio and RPM level affected $\mathrm{NH}_{3}-\mathrm{N}$ and IVDMD and were highest in R:C of 0:100 with $0,4 \mathrm{mg}$ of RPM and 40:60 with $8 \mathrm{mg}$ of RPM, respectively. Moreover, interaction of $\mathrm{R}: \mathrm{C}$ ratio and RPM level significantly increased total volatile fatty acids and propionate concentration whereas lower acetate, acetate to propionate ratios and $\mathrm{CH}_{4}$ production in $\mathrm{R}: \mathrm{C}$ of 20:80 with $8 \mathrm{mg}$ of RPM. Moreover, the two factors, R:C ratio and RPM level influenced the protozoal population and the percentage of methanogens in the total bacteria population. In addition, the use of real-time PCR found that a high level of concentrate in the diet remarkably decreased three cellulolytic bacteria numbers $(F$. succinogenes, R. flavefaciens and R. albus). Based on this study, it is suggested that the ratio of R:C at 40:60 and RPM level at $12 \mathrm{mg}$ could improve ruminal fluid fermentation in terms of reducing fermentation losses, thus improving VFA profiles and ruminal ecology. (Key Words : Rain Tree Pod Meal, Roughage to Concentrate Ratio, Fermentation, Methane Production, Rice Straw)
\end{abstract}

\section{INTRODUCTION}

In the process of ruminal fermentation, $2-12 \%$ of ingested gross energy is converted to methane, which not only lowers the efficiency of feedstuff utilization, but also contributes to global warming (Johnson and Johnson, 1995). Methane from livestock accounted for $38 \%$ of the green house gases emitted (McGinn et al., 2004). Therefore, inhibition of methane production from livestock can improve feed efficiency and potentially have long-term environmental benefits. Dietary manipulation can help suppress methane emission from ruminants by inhibiting rumen microbes involved in methane formation, or by diverting hydrogen away from methane production during ruminal fermentation (McGinn et al., 2004). The type of feeds offered to the ruminant can have a major effect on ruminal methane production. Methane production decreased when the proportion of dietary concentrate increased (Yan

\footnotetext{
* Corresponding Author : Metha Wanapat. Tel : +66- 43-202368, Fax : +66-43-202368, E-mail : metha@kku.ac.th Submitted May 6, 2011; Accepted Jul. 22, 2011; Revised Jul. 26, 2011
}

et al., 2000). The roughage to concentrate (R:C) ratio has an impact on the rumen fermentation and hence the acetate: propionate ratio. An increased proportion of concentrate diet changes ruminal volatile fatty acid (VFAs) concentrations in such a way that less acetate and more propionate (Walichnowski and Lawrence, 1982) is produced. However, increased levels of concentrates may result in health problems e.g. acidosis and high cost of production.

Several secondary compounds contained in plants can be used for rumen manipulation and be a cost-effective way to improve the performance of ruminants. Effects of some medicinal plants, plant extracts or essential oils on ruminal fermentation have already been reported (Evans and Martin, 2000). Tropical foliages or legumes normally contain high or medium contents of secondary compounds. Among these compounds are the saponins and tannins, which have been shown to exert a specific effect against rumen protozoal (Wang et al., 2000; Animut et al., 2008) and reduced ruminal methane production (Grainger et al., 2009). Protozoa contributes hydrogen for the reduction of $\mathrm{CO}_{2}$ to 
$\mathrm{CH}_{4}$ by the methanogens. Methane production is higher when protozoa are present than when they are absent or present in low in numbers (Jouany and Lassalas, 1997). There are many reports indicating the inhibitory effect of tannins on rumen protozoa. For instance, Hess et al. (2006) reported that supplementation with a tannin-rich legume with $25 \mathrm{~g}$ tannins/kg dietary dry matter (DM) could decrease methane emission by $13 \%$ without affecting energy retention. Chanthakhoun et al. (2011) found that Phaseolus calcaratus hay, $2.8 \%$ of condensed tannins (CT), reduced methane gas production in swamp buffalo. However, the mechanisms of inhibition of rumen protozoa have not been known (Patra and Saxena, 2011). However, higher levels (5-9\%) tannins may reduce plant cell wall digestibility by binding bacterial enzymes and/or forming indigestible complexes with cell wall carbohydrates (Barry, 1983; Reed et al., 1990).

Rain tree (Samanea saman) is local tree legume grown in tropical and sub-tropical area. Pods are black-brown, filled with a sticky, sweet, brownish pulp and falls during the dry season. It is edible and nutritious for livestock and make an excellent feed supplement (George and Craig, 2006). Rain tree pod contains $18.1 \%$ of crude protein (CP), $4.0 \%$ of CT, $18.2 \%$ of total sugar and $8.4 \%$ of sucrose which gives them a potential to use in rumen manipulation aimed at improving the performance of ruminants. (George and Craig, 2006). Therefore, the objective of this study was to determine roughage to concentrate $(\mathrm{R}: \mathrm{C})$ ratio with rain tree pod meal (RPM) supplementation on improving ruminal fermentation in dairy steer rumen fluid using an in vitro gas production technique.

\section{MATERIALS AND METHODS}

\section{Diets and experimental design}

Twenty-four total mixed diets were formulated according to a $6 \times 4$ factorial arrangement in a completely randomized design (CRD). The diets were 6 levels of $\mathrm{R}: \mathrm{C}$ ratio $(100: 0,80: 20,60: 40,40: 60,20: 80$ and 0:100) with 4 levels of rain tree pod meal (RPM) $(0,4,8$ and $12 \mathrm{mg})$. Concentrates were formulated to contain cassava chip, rice bran and molasses as an energy source while, coconut meal, palm kernel meal and urea as the protein sources. The $3.5 \%$ urea treated rice straw was used as a roughage source, by adding $3.5 \mathrm{~g}$ urea in $100 \mathrm{ml}$ water to $100 \mathrm{~g}$ air-dry $(91 \%$ DM) straw. The relevant volume of urea solution was sprayed onto a stack of whole straw bales and then covering the stack with a plastic sheet for a minimum of 10 days before feeding directly to animals (Wanapat, 2000). The RPM was prepared by oven-drying at $60^{\circ} \mathrm{C}$ for 3 days then grinding. Feed ingredients and chemical composition of the diets are shown in Table 1.
Table 1. Ingredients and chemical composition ( $/ \mathrm{kg} \mathrm{DM})$ of concentrate, $3.5 \%$ urea treated rice straw and rain tree pod meal used in the experiment

\begin{tabular}{|c|c|c|c|}
\hline Item & Concentrate & $\mathrm{UTRS}^{1}$ & $\mathrm{RPM}^{2}$ \\
\hline \multicolumn{4}{|c|}{ Ingredient (kg of DM) } \\
\hline Cassava chip & 63.6 & & \\
\hline Rice bran & 10.0 & & \\
\hline Coconut meal & 11.5 & & \\
\hline Palm kernel meal & 7.4 & & \\
\hline Urea & 3.0 & & \\
\hline Molasses & 2.0 & & \\
\hline Mineral premix & 1.0 & & \\
\hline Salt & 1.0 & & \\
\hline Sulfur & 0.5 & & \\
\hline \multicolumn{4}{|l|}{ Chemical composition } \\
\hline $\mathrm{DM}(\%)$ & 86.7 & 50.6 & 93.1 \\
\hline $\mathrm{OM}$ & 94.6 & 90.1 & 96.5 \\
\hline $\mathrm{CP}$ & 14.1 & 5.8 & 18.1 \\
\hline $\mathrm{CT}$ & - & - & 4.0 \\
\hline $\mathrm{NDF}$ & 18.7 & 71.4 & 29.2 \\
\hline $\mathrm{ADF}$ & 15.4 & 56.3 & 24.6 \\
\hline Ether extract & 1.9 & 1.3 & 1.4 \\
\hline $\mathrm{TDN}^{3}$ & 78.6 & - & - \\
\hline
\end{tabular}

${ }^{1}$ UTRS $=3.5 \%$ urea treated rice straw.

${ }^{2} \mathrm{RPM}=$ Rain tree pod meal. ${ }^{3}$ Calculated value.

\section{Animals and inocula}

Two, 1-year-old, rumen fistulated dairy steers with an initial BW of $250 \pm 15 \mathrm{~kg}$ were used as rumen fluid donors. Dairy steer rumen fluid was collected from animals fed with a R:C of 60:40 (14\% CP and 78.6\% TDN, dry matter basis). Animals were housed in individual pens and had continuous access to fresh water and vitamin/mineral block for 15 days.

On day 15 , about $1,000 \mathrm{ml}$ rumen liquor was taken through the cannula of each dairy steer immediately before the morning feeding and strained through four layers of cheesecloth into an Erlenmeyer flask.

\section{In vitro fermentation of substrates}

Samples of each total mix substrate $(200 \mathrm{mg})$ were weighed into $50 \mathrm{ml}$ serum bottles. Ruminal fluid from each dairy steer was mixed with the artificial saliva solution of Menke and Steingass (1988) in a proportion 2:1 ( $\mathrm{ml} / \mathrm{ml})$ at $39^{\circ} \mathrm{C}$ under continuous flushing with $\mathrm{CO}_{2}$. Thirty millilitres of rumen inoculum mixture were added into each bottle under $\mathrm{CO}_{2}$ flushing. Bottles were sealed with rubber stoppers and aluminium caps and incubated at $39^{\circ} \mathrm{C}$ for $96 \mathrm{~h}$. 


\section{Sample and analysis}

During the incubation, the gas production was measured immediately after incubation and after $0,1,2,3,4,6,8,10$, $12,24,36,48,72$ and $96 \mathrm{~h}$ by using a pressure transducer and a calibrated syringe. Cumulative gas production data were fitted to the model of Ørskov and McDonald (1979) as follows:

$$
y=a+b\left(1-e^{-c t}\right)
$$

where $\mathrm{a}=$ the gas production from the immediately soluble fraction, $b=$ the gas production from the insoluble fraction, $\mathrm{c}=$ the gas production rate constant for the insoluble fraction $(\mathrm{b}), \mathrm{t}=$ incubation time, $(\mathrm{a}+\mathrm{b})=$ the potential extent of gas production. $\mathrm{y}=$ gas produced at time "t".

Inoculum ruminal fluid was sampled at $0,4,6,12$ and $24 \mathrm{~h}$ post inoculations. Rumen fluid samples were then filtered through four layers of cheesecloth. Samples were divided into 3 portions; the first portion was centrifuged at $16,000 \times \mathrm{g}$ for $15 \mathrm{~min}$, and the supernatant was stored at $-20^{\circ} \mathrm{C}$ before $\mathrm{NH}_{3}-\mathrm{N}$ analysis using the micro-Kjeldahl methods AOAC (1990) and VFA analysis using HPLC (Samuel et al., 1997). The second portion was fixed with $10 \%$ formalin solution in a sterilized $0.9 \%$ saline solution for a total direct count of protozoa made by the methods of Galyean (1989) based on the use of a hemocytometer (Boeco, Hamburg, Germany). The final portion was stored at $-20^{\circ} \mathrm{C}$ for DNA extraction (Yu and Morrison, 2004). In vitro degradability was determined after termination of incubation, when the contents were filtered through preweighed Gooch crucibles and residual dry matter was estimated. The percent loss in weight was determined and presented as in vitro dry matter degradability (IVDMD). The dried feed sample and residue left above was ashed at $550^{\circ} \mathrm{C}$ for determination of in vitro organic matter degradability (IVOMD) (Tilley and Terry, 1963). Content of condensed tannins in RPM was analysed by using the modified vanillin- $\mathrm{HCl}$ method based on Burns (1971). Calculation of ruminal methane $\left(\mathrm{CH}_{4}\right)$ production using VFA proportions according to Moss et al. (2000) as follows:

$$
\begin{aligned}
& \mathrm{CH}_{4} \text { production } \\
& =0.45 \text { (acetate) }-0.275 \text { (propionate) }+0.4 \text { (butyrate) }
\end{aligned}
$$

\section{Rumen microbial population}

Community deoxyribonucleic acids (DNA) extraction : Community DNA was extracted from $2.0 \mathrm{ml}$ of rumen fluid of each sample by the $\mathrm{RBB}+\mathrm{C}$ method ( $\mathrm{Yu}$ and Morrison, 2004), which was shown to substantially increase DNA yields. The quality and quantity of these DNA samples were also determined by agarose gel electrophoresis and spectrophotometry.

Primers and polymerase chain reaction (PCR) : Primers for Fibrobactor succinogenes, Fs219f (5'GGT ATG GGA TGA GCT TGC-3') and Fs654r (5'-GCC TGC CCC TGA ACT ATC- 3'), were selected to allow amplification (446-bp product) of all $10 \mathrm{~F}$. succinogenes strains deposited in GenBank. For Ruminococcus albus primers, Ra1281f (5'CCC TAA AAG CAG TCT TAG TTC G-3') and Ra1439r (5' CCT CCT TGC GGT TAG AAC A- 3') (175-bp product). Ruminococcus flavefaciens primers, Rf154f (5'-TCT GGA AAC GGA TGG TA-3') and Rf425r (5'- CCT TTA AGA CAG GAG TTT ACA A-3'), were also selected to allow species-specific amplification (295 bp) of all seven $R$. flavefaciens strains deposited in GenBank. All these primer sets were previously published by Koike and Kobayashi (2001). For methanogens primers, forward primers (5'TTCGGTGGATCDCARAGRGC-3') and reverse primers (5'-GBARGTCGW- AWCCGTAGAATCC -3') were employed as described by Denman et al. (2005). PCR conditions for F. succinogenes were as follows: $30 \mathrm{~s}$ at $94^{\circ} \mathrm{C}$ for denaturing, $30 \mathrm{~s}$ at $60^{\circ} \mathrm{C}$ for annealing and $30 \mathrm{~s}$ at $72^{\circ} \mathrm{C}$ for extension (48 cycles), except for 9 min denaturation in the first cycle and $10 \mathrm{~min}$ extension in the last cycle. Amplification of 16S rRNA for the other two species was carried out similarly except an annealing temperature of $55^{\circ} \mathrm{C}$ was used. The PCR conditions for methanogens were as follows; $30 \mathrm{~s}$ at $94^{\circ} \mathrm{C}$ for denaturing, $30 \mathrm{~s}$ at $58^{\circ} \mathrm{C}$ for annealing and $90 \mathrm{~s}$ at $72^{\circ} \mathrm{C}$ for extension (35 cycles) (Wright et al., 2004).

Real-time PCR : The targeted bacteria were cellulolytic bacteria ( $F$. succinogenes, $R$. albus and $R$. flavefaciens) and methanogens. To establish a quantitative assay, we amplified target 16s rDNA of each species by using specific primers and PCR conditions as described previously, the purified DNA was quantified by spectrophotometry by comparing the products with serial 10- fold dilutions from $10^{1}$ to $10^{8}$ DNA copies of the previously quantified DNA standards. Real-time PCR amplification and detection were performed in a Chromo 4TM system (Bio-Rad, USA). In brief, Biostools QuantiMix Easy SYG Kit was used for PCR amplification. Samples were assayed in duplicate in a $20 \mu \mathrm{l}$ reaction mixture contained 4-6 $\mathrm{mM} \mathrm{MgCl}, 10 \mu \mathrm{l}$ of Mastermix (including; Taq DNA polymerase, reaction buffer, dNTP mixture, $\mathrm{MgCl}_{2}$ and SybrGreen), $2 \mu \mathrm{l}$ of DNA template, and $0.8 \mu \mathrm{l}$ of each primer $(10 \mu \mathrm{M} / \mu \mathrm{l})$.

\section{Statistical analysis}

All data were analyzed as a $6 \times 4$ factorial arrangement in a completely randomized design (CRD) using the general linear procedure in PROC GLM of SAS (1996). The statistical model included terms for R:C ratio, RPM level, and the $\mathrm{R}: \mathrm{C}$ ratio $\times \mathrm{RPM}$ level interactions. Trend of ratios 
responded was performed by orthogonal polynomials.

\section{RESULTS}

Gas kinetics and cumulative gas production of each substrate treatments are presented in Table 2. Gas kinetics, extent rate $(\mathrm{C})$ was linearly increased while, rate $(\mathrm{a}+\mathrm{b})$ was linearly decreased with increasing level of concentrate. Cumulative gas production at $96 \mathrm{~h}$ was influenced by different $\mathrm{R}: \mathrm{C}$ ratios which were higher $(\mathrm{p}<0.05)$ in $\mathrm{R}: \mathrm{C}$ of 40:60. In addition, interaction of $\mathrm{R}: \mathrm{C}$ ratio and $\mathrm{RPM}$ level affected IVDMD and was highest in R:C of 40:60 with 8

Table 2. The effect of roughage to concentrate ratio with rain tree pod meal on gas kinetics, gas production and degradability from in vitro incubation with rumen fluid

\begin{tabular}{|c|c|c|c|c|c|c|c|c|c|}
\hline \multirow[b]{2}{*}{ Trt } & \multirow{2}{*}{$\mathrm{R}: \mathrm{C}^{1}$ ratio } & \multirow{2}{*}{$\begin{array}{c}\mathrm{RPM}^{2} \\
(\mathrm{mg})\end{array}$} & \multicolumn{4}{|c|}{ Gas kenetics $^{3}$} & \multirow{2}{*}{$\begin{array}{c}\text { Gas }(96 \mathrm{~h}) \mathrm{ml} \\
/ 0.2 \mathrm{~g} \mathrm{DM} \\
\text { substrate }\end{array}$} & \multicolumn{2}{|c|}{ In vitro degradability (\%) } \\
\hline & & & a & $\mathrm{b}$ & $\mathrm{c}$ & $a+b$ & & IVDMD & IVOMD \\
\hline 1 & $100: 0$ & 0 & -5.1 & 75.8 & 0.02 & 70.7 & 59.2 & 55.7 & 79.9 \\
\hline 2 & & 4 & -4.8 & 77.5 & 0.02 & 72.6 & 62.0 & 39.3 & 57.0 \\
\hline 3 & & 8 & -4.8 & 73.8 & 0.02 & 68.9 & 59.9 & 42.8 & 67.0 \\
\hline 4 & & 12 & -4.4 & 78.5 & 0.02 & 73.9 & 63.8 & 70.9 & 70.0 \\
\hline 5 & $80: 20$ & 0 & -3.9 & 75.6 & 0.03 & 71.6 & 66.8 & 82.4 & 77.6 \\
\hline 6 & & 4 & -2.0 & 70.8 & 0.03 & 68.8 & 63.7 & 68.5 & 76.9 \\
\hline 7 & & 8 & -0.5 & 72.0 & 0.03 & 71.5 & 66.8 & 79.3 & 76.6 \\
\hline 8 & & 12 & -1.6 & 72.3 & 0.03 & 70.7 & 65.8 & 63.7 & 83.0 \\
\hline 9 & $60: 40$ & 0 & -0.8 & 69.9 & 0.04 & 69.1 & 67.4 & 78.6 & 87.0 \\
\hline 10 & & 4 & 2.6 & 68.1 & 0.04 & 70.7 & 70.4 & 55.6 & 71.7 \\
\hline 11 & & 8 & 0.1 & 69.2 & 0.04 & 69.4 & 68.1 & 75.8 & 81.3 \\
\hline 12 & & 12 & 1.2 & 63.9 & 0.03 & 65.1 & 62.8 & 83.9 & 84.5 \\
\hline 13 & $40: 60$ & 0 & -2.2 & 70.2 & 0.05 & 67.9 & 68.8 & 76.6 & 81.6 \\
\hline 14 & & 4 & -0.7 & 70.7 & 0.05 & 70.0 & 71.4 & 79.7 & 81.7 \\
\hline 15 & & 8 & -3.0 & 68.0 & 0.05 & 65.0 & 65.8 & 87.5 & 90.7 \\
\hline 16 & & 12 & 1.5 & 68.9 & 0.05 & 70.4 & 71.2 & 73.8 & 90.5 \\
\hline 17 & $20: 80$ & 0 & -0.4 & 65.7 & 0.07 & 65.2 & 67.2 & 81.3 & 87.2 \\
\hline 18 & & 4 & -1.8 & 68.4 & 0.08 & 66.6 & 69.0 & 80.7 & 88.4 \\
\hline 19 & & 8 & -1.3 & 65.5 & 0.07 & 64.2 & 66.0 & 71.2 & 82.3 \\
\hline 20 & & 12 & -1.6 & 68.1 & 0.07 & 66.5 & 68.5 & 58.1 & 67.9 \\
\hline 21 & $0: 100$ & 0 & -4.5 & 68.2 & 0.09 & 63.7 & 65.2 & 52.7 & 62.6 \\
\hline 22 & & 4 & -6.4 & 67.4 & 0.09 & 60.9 & 63.4 & 53.9 & 59.1 \\
\hline 23 & & 8 & -5.3 & 69.3 & 0.09 & 64.0 & 66.0 & 58.5 & 68.9 \\
\hline 24 & & 12 & -5.2 & 69.6 & 0.09 & 64.4 & 66.5 & 70.0 & 79.0 \\
\hline SEM & & & 0.08 & 0.22 & 0.01 & 0.25 & 0.25 & 0.45 & 0.45 \\
\hline \multicolumn{10}{|c|}{ Comparison } \\
\hline & & & $* *$ & $* *$ & $* *$ & $*$ & $*$ & $* *$ & $* *$ \\
\hline & of RPM & & 0.28 & 0.91 & 0.14 & 0.92 & 0.93 & 0.11 & 0.20 \\
\hline & tion & & 0.33 & 0.96 & 0.83 & 0.99 & 0.97 & $* *$ & 0.19 \\
\hline \multicolumn{10}{|c|}{ Orthogonal polynomial } \\
\hline & & & 0.66 & $* *$ & $* *$ & $* *$ & 0.05 & 0.15 & 0.74 \\
\hline & uad) & & $* *$ & $* *$ & 0.27 & 0.54 & $* *$ & $* *$ & $* *$ \\
\hline & ubic) & & 0.70 & 0.80 & 0.97 & 0.82 & 0.94 & 0.72 & 0.27 \\
\hline & uart) & & 0.44 & 0.92 & 0.53 & 0.98 & 0.93 & 0.18 & 0.56 \\
\hline & uint) & & $*$ & 0.11 & 0.83 & 0.60 & 0.57 & 0.16 & 0.49 \\
\hline & (in) & & 0.07 & 0.61 & 0.54 & 0.96 & 0.91 & 0.79 & 0.67 \\
\hline & quad) & & 0.51 & 0.69 & 0.04 & 0.70 & 0.96 & 0.07 & 0.11 \\
\hline & (cubic) & & 0.69 & 0.74 & 0.34 & 0.56 & 0.50 & 0.08 & 0.16 \\
\hline
\end{tabular}

${ }^{1} \mathrm{R}: \mathrm{C}=$ Roughage:concentrate ratio. ${ }^{2} \mathrm{RPM}=$ Rain tree pod meal.

${ }^{3} \mathrm{a}=$ The gas production from the immediately soluble fraction, $\mathrm{b}=$ The gas production from the insoluble fraction. $\mathrm{c}=$ The gas production rate constant for the insoluble fraction (b), $\mathrm{a}+\mathrm{b}=$ The gas potential extent of gas production. ${ }^{*} \mathrm{p}<0.05, * * \mathrm{p}<0.01$. 
mg of RPM while, IVOMD was quadratically increased with increasing level of concentrate in the diet (Table 2).

The $\mathrm{NH}_{3}-\mathrm{N}$ concentration of all treatments ranged from 13.9-32.1 $\mathrm{mg} / \mathrm{dl}$ (Table 3 ). In the in vitro gas production technique, $\mathrm{NH}_{3}-\mathrm{N}$ concentration was highest in $\mathrm{R}: \mathrm{C}$ of 0:100 with 0 and $4 \mathrm{mg}$ of RPM (32.1 and $30.9 \mathrm{mg} / 100 \mathrm{ml}$ respectively). While $\mathrm{NH}_{3}-\mathrm{N}$ was found to be the lowest in $\mathrm{R}: \mathrm{C}$ of 100:0 and 40:60 with $12 \mathrm{mg}$ of RPM (13.9 and 14.5 $\mathrm{mg} / 100 \mathrm{ml}$, respectively).

Interaction between $\mathrm{R}: \mathrm{C}$ ratio and RPM level affected the total VFAs and individual VFAs production (Table 3). Total VFA concentrations in R:C of 20:80 with $8 \mathrm{mg}$ of

Table 3. The effect of roughage to concentrate ratio with rain tree pod meal on in vitro volatile fatty acids $(\mathrm{VFAs}), \mathrm{NH}_{3}-\mathrm{N}$, methane production and protozoal population

\begin{tabular}{|c|c|c|c|c|c|c|c|c|c|c|}
\hline Trt & $\begin{array}{l}\mathrm{R}: \mathrm{C}^{1} \\
\text { ratio }\end{array}$ & $\begin{array}{l}\mathrm{RPM}^{2} \\
(\mathrm{mg})\end{array}$ & $\begin{array}{l}\text { Total VFA } \\
(\mathrm{mM} / \mathrm{L})\end{array}$ & $\begin{array}{l}\mathrm{C} 2 \\
(\%)\end{array}$ & $\begin{array}{l}\mathrm{C} 3 \\
(\%)\end{array}$ & $\begin{array}{l}\mathrm{C} 4 \\
(\%)\end{array}$ & $\begin{array}{l}\mathrm{C} 2: \mathrm{C} 3 \\
\text { ratio }\end{array}$ & $\begin{array}{c}\mathrm{NH}_{3}-\mathrm{N} \\
(\mathrm{mg} / 100 \mathrm{ml})\end{array}$ & $\begin{array}{c}\mathrm{CH}_{4} \text { production } \\
(\mathrm{mM} / \mathrm{L})\end{array}$ & $\begin{array}{c}\text { Protozoal } \\
\text { population } \\
\left(\times 10^{5}\right)\end{array}$ \\
\hline 1 & 100: 0 & 0 & 22.1 & 74.1 & 15.9 & 10 & 4.7 & 21.9 & 29.8 & 6.6 \\
\hline 2 & & 4 & 41.2 & 71.4 & 17.4 & 11.2 & 4.1 & 24.1 & 28.8 & 5.5 \\
\hline 3 & & 8 & 23.6 & 67.2 & 22 & 10.8 & 3.1 & 26.7 & 25.7 & 2.2 \\
\hline 4 & & 12 & 34.9 & 70.6 & 18.4 & 11.0 & 3.8 & 13.9 & 28.1 & 1.1 \\
\hline 5 & $80: 20$ & 0 & 41.3 & 69.8 & 18.5 & 11.7 & 3.8 & 22.9 & 28.1 & 4.4 \\
\hline 6 & & 4 & 42.7 & 66.1 & 24.6 & 9.3 & 2.7 & 26.8 & 23.9 & 1.5 \\
\hline 7 & & 8 & 33.4 & 64.5 & 28.1 & 7.4 & 2.3 & 23.5 & 21.4 & 1.5 \\
\hline 8 & & 12 & 41.2 & 64.2 & 26.5 & 9.3 & 2.4 & 27.5 & 22.6 & 1.1 \\
\hline 9 & $60: 40$ & 0 & 39.3 & 69.3 & 19.5 & 11.2 & 3.6 & 21.2 & 27.4 & 3.3 \\
\hline 10 & & 4 & 45.1 & 68.5 & 19.6 & 11.9 & 3.5 & 24.0 & 27.4 & 2.5 \\
\hline 11 & & 8 & 31.0 & 60.3 & 29.6 & 10.1 & 2.0 & 29.7 & 20.5 & 1.5 \\
\hline 12 & & 12 & 39.0 & 59.6 & 29.0 & 11.4 & 2.1 & 25.4 & 21.0 & 1.5 \\
\hline 13 & $40: 60$ & 0 & 41.1 & 69.6 & 20.0 & 10.4 & 3.5 & 14.8 & 27.0 & 2.0 \\
\hline 14 & & 4 & 43.3 & 67.2 & 22.6 & 10.2 & 3.0 & 18.1 & 25.3 & 1.5 \\
\hline 15 & & 8 & 47.8 & 58.2 & 30.5 & 11.3 & 1.9 & 21.7 & 20.0 & 1.5 \\
\hline 16 & & 12 & 42.1 & 59.5 & 32.1 & 8.4 & 1.9 & 14.5 & 18.8 & 1.1 \\
\hline 17 & $20: 80$ & 0 & 42.2 & 65.8 & 26.1 & 8.1 & 2.5 & 30.1 & 22.8 & 2.0 \\
\hline 18 & & 4 & 43.1 & 61.1 & 28.6 & 10.3 & 2.1 & 25.4 & 21.2 & 1.1 \\
\hline 19 & & 8 & 53.2 & 56.4 & 32.9 & 10.7 & 1.7 & 28.2 & 18.3 & 1.1 \\
\hline 20 & & 12 & 45.9 & 57.3 & 29.6 & 13.1 & 1.9 & 21.1 & 20.7 & 1.5 \\
\hline 21 & $0: 100$ & 0 & 44.7 & 64.9 & 25.6 & 9.5 & 2.5 & 32.1 & 23.2 & 2.2 \\
\hline 22 & & 4 & 45.9 & 64.3 & 26.5 & 9.2 & 2.4 & 30.9 & 22.6 & 2.2 \\
\hline 23 & & 8 & 49.9 & 56.4 & 33.2 & 10.4 & 1.7 & 28.9 & 18.1 & 1.1 \\
\hline 24 & & 12 & 45.1 & 57.9 & 28.4 & 13.7 & 2.0 & 25.7 & 21.5 & 1.5 \\
\hline SEM & & & 1.05 & 0.26 & 0.06 & 0.26 & 0.05 & 1.28 & 0.14 & 0.05 \\
\hline \multicolumn{11}{|c|}{ Comparison } \\
\hline $\mathrm{R}: \mathrm{C}$ & & & $* *$ & $* *$ & $* *$ & 0.05 & $* *$ & $* *$ & $* *$ & $*$ \\
\hline Les & of RPM & & $*$ & $*$ & $* *$ & * & $* *$ & $*$ & $*$ & * \\
\hline Int & tion & & $*$ & $* *$ & $* *$ & $* *$ & $* *$ & $*$ & * & 0.10 \\
\hline \multicolumn{11}{|c|}{ Orthogonal polynomial } \\
\hline $\mathrm{R}: \mathrm{C}$ & & & $* *$ & $* *$ & $* *$ & 0.47 & $* *$ & $* *$ & $* *$ & $* *$ \\
\hline $\mathrm{R}: \mathrm{C}$ & uad) & & $* *$ & $* *$ & $* *$ & 0.19 & $* *$ & 0.73 & $* *$ & $*$ \\
\hline $\mathrm{R}: \mathrm{C}$ & ubic) & & 0.61 & 0.80 & 0.32 & 0.18 & $* *$ & $* *$ & 0.22 & 0.63 \\
\hline $\mathrm{R}: \mathrm{C}$ & uart) & & $* *$ & $*$ & $* *$ & 0.06 & $* *$ & 0.54 & $* *$ & 0.38 \\
\hline $\mathrm{R}: \mathrm{C}$ & uint) & & $* *$ & 0.06 & 0.38 & * & 0.38 & $* *$ & 0.10 & 0.42 \\
\hline $\mathrm{RP}$ & lin) & & 0.54 & $* *$ & $* *$ & $*$ & $* *$ & $* *$ & $* *$ & $* *$ \\
\hline $\mathrm{RP}$ & quad) & & $* *$ & $* *$ & $* *$ & 0.26 & $* *$ & $*$ & $* *$ & 0.72 \\
\hline $\mathrm{RP}$ & cubic) & & $* *$ & $* *$ & $* *$ & 0.06 & $* *$ & $*$ & $* *$ & 0.95 \\
\hline
\end{tabular}

${ }^{1} \mathrm{R}: \mathrm{C}=$ Roughage:concentrate ratio. ${ }^{2} \mathrm{RPM}=$ Rain tree pod meal. $* \mathrm{p}<0.05, * * \mathrm{p}<0.01$.

${ }^{3}$ Calculated according to Moss et al. (2000) $\mathrm{CH}_{4}$ production $=0.45$ (acetate) -0.275 (propionate) +0.4 (butyrate) 
RPM $(53.2 \mathrm{mM} / \mathrm{L})$ were higher than other treatments ( $\mathrm{p}<0.05$ ). In addition, R:C of 0:100 and 20:80 with $8 \mathrm{mg}$ of RPM and 40:60 with $12 \mathrm{mg}$ of RPM resulted in a higher $(\mathrm{p}<0.01)$ proportion of propionate $(33.2,32.9$ and 32.1 $\mathrm{mM} / \mathrm{L}$, respectively) and a lower $(\mathrm{p}<0.01)$ proportion of acetate and acetate to propionate ratio. While the proportion of butyrate was highest $(\mathrm{p}<0.01)$ in $\mathrm{R}: \mathrm{C}$ of $0: 100$ and 20:80 with $12 \mathrm{mg}$ of RPM (13.7 and $13.1 \mathrm{mM} / \mathrm{L}$, respectively). Calculation of ruminal methane $\left(\mathrm{CH}_{4}\right)$ production using VFA proportions according to Moss et al. (2000) showed that methane production was influenced by interaction of $\mathrm{R}: \mathrm{C}$ ratio and $\mathrm{RPM}$ level, which was lower $(\mathrm{p}<0.05)$ in $\mathrm{R}: \mathrm{C}$ of 0:100 and 20:80 with $8 \mathrm{mg}$ of RPM and 40:60 with 12 $\mathrm{mg}$ of RPM $(18.1,18.3$ and $18.8 \mathrm{mM} / \mathrm{L})$. Under the current

(a)
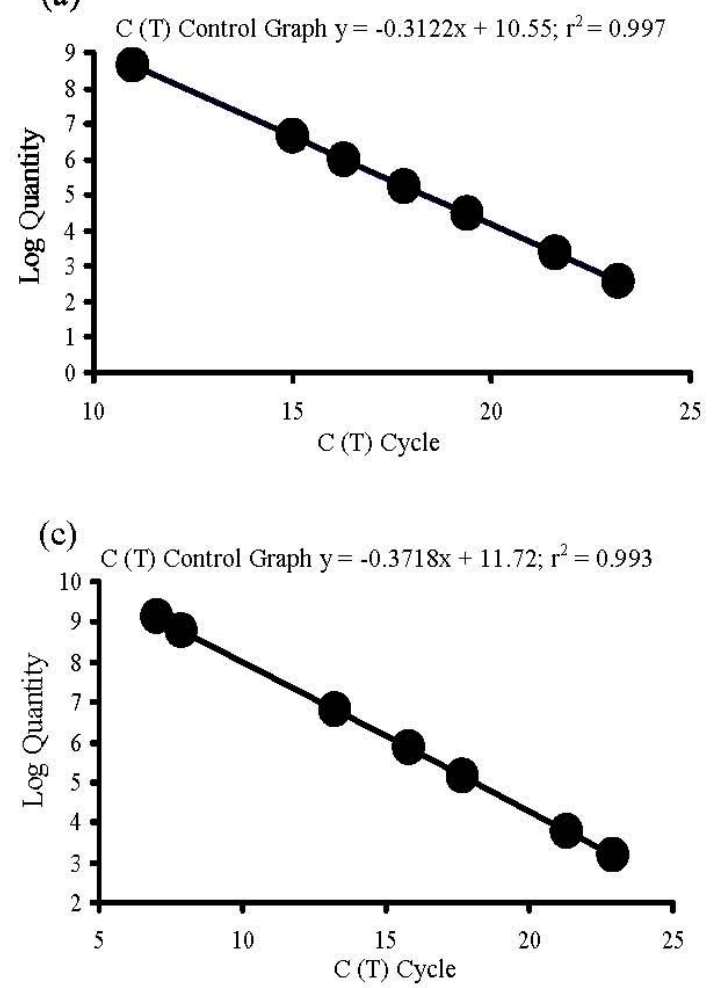

study, the two factors, R:C ratio and RPM level affected the protozoal population which was lower $(\mathrm{p}<0.05)$ in $\mathrm{R}: \mathrm{C}$ of 20:80 and 40:60, respectively and RPM level at $12 \mathrm{mg}$.

External standards for real-time PCR were prepared from a simulated rumen matrix. For each standard, linear regressions derived from the threshold cycle $[\mathrm{C}(\mathrm{T})]$ of each DNA dilution versus the log quality (Figure 1) were calculated. Logarithms of the DNA concentration (copies $/ \mathrm{ml}$ ) were plotted against the calculated means (Figure 1), obtaining a straight line of equations $\mathrm{y}=$ $-0.3122 x+10.55, y=-0.2864 x+12.10, y=-0.3718 x+11.72$, $y=-0.1337 x+9.57$ and $y=-0.2692 x+11.99$ (where $y$ is the $\log$ of DNA concentration and $\mathrm{x}$ is the $\mathrm{Ct}$ ), with a linear correlation coefficient $\left(\mathrm{r}^{2}\right)$ of $0.997,0.997,0.993,0.995$ and

(b)

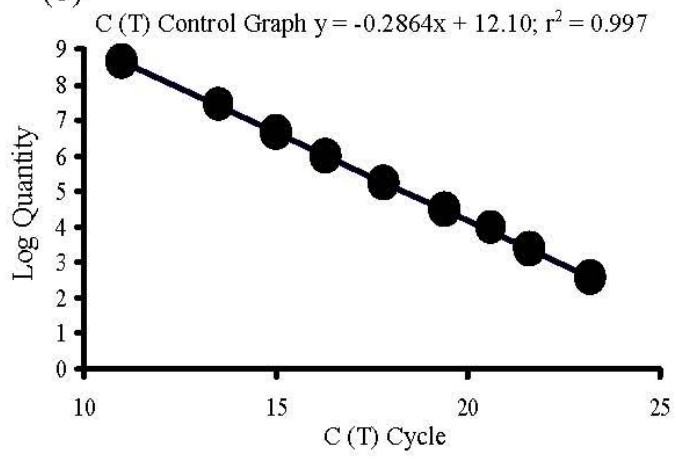

(d)

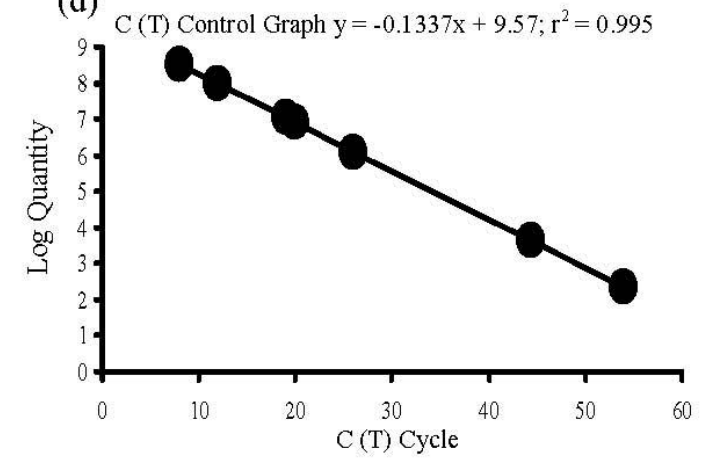

(e) $\mathrm{C}(\mathrm{T})$ Control Graph $\mathrm{y}=-0.2692 \mathrm{x}+11.99 ; \mathrm{r}^{2}=0.991$

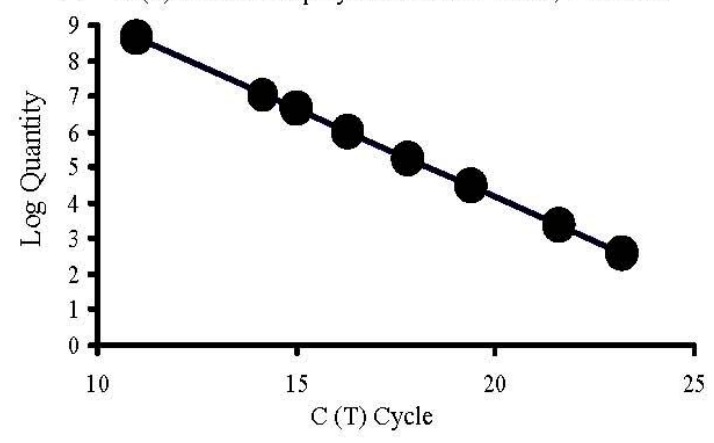

Figure 1. The standard curves obtained by plotting the logarithm of DNA concentration for Total bacteria (a), Methanogens (b), F. succinogenes (c), R. flavefaciens (d) and R. albus (e) versus threshold cycle (Ct) for population quantification by using real time PCR. 
0.991 for total bacteria (Figure 1a), methanogens (Figure level at $12 \mathrm{mg}$.

1b), F. succinogenes (Figure 1c), R. flavefaciens (Figure 1d) and $R$. albus (Figure 1e), respectively. These equations were used to quantify DNA from rumen digesta samples. The accuracy of each real-time PCR was validated by quantifying known numbers of target species templates (Total bacteria, Methanogens, $F$. succinogenes, $R$. flavefaciens and R. albus) and is shown in Table 4. The interaction of $\mathrm{R}: \mathrm{C}$ ratio and RPM level had an effect on the total bacteria present, which highest $(\mathrm{p}<0.01)$ in $\mathrm{R}: \mathrm{C}$ of 20:80 with $8 \mathrm{mg}$ of RPM $\left(43.6 \times 10^{9}\right)$. The number of methanogens present linearly increased $(p<0.05)$ with an increasing level of concentrate in the diet. However, the percentage of methanogens in the total bacterial population linearly decreased with an increasing level of concentrate and RPM. Predominant cellulolytic bacteria (R. flavefaciens, $F$. succinogenes and $R$. alus) were variable between substrate treatments. The $F$. succinogenes population was found to be the highest across substrate treatments especially in R:C of $60: 40$ with $8 \mathrm{mg}$ of RPM $\left(8.3 \times 10^{8}\right.$ copies $/ \mathrm{ml}$ ) as compared to $R$. flavefaciens, and $R$. albus. However, the $R$. flaveflaciens population was found highest in R:C of $60: 40$ with $12 \mathrm{mg}$ of RPM $\left(8.1 \times 10^{7}\right.$ copies $\left./ \mathrm{ml}\right)$, whereas $R$. albus was higher in R:C of 60:40 and RPM

\section{DISCUSSION}

Gas kinetics and cumulative gas production was influenced by different $\mathrm{R}: \mathrm{C}$ ratios, especially the constant rate (c) which linearly increased with an increasing level of concentrate. While cumulative gas production was highest in $\mathrm{R}: \mathrm{C}$ of 40:60. These findings suggest that the inclusion of high levels of concentrate results in an increasing rate and extent of fermentation of the inoculums. Similarly with Lunsin and Wanapat (2010) who reported that gas production and gas kenetic were linearly increased with increasing levels of concentrate from 30 to $70 \%$. However, a high level of concentrate may lower the $\mathrm{pH}$ and impact on the microbial population (Slyter, 1976).

The in vitro degradability of both DM and OM quadratically increased with an increasing level of concentrate. This could be due to a corresponding increase of microbes which then increased degradability. However, an all concentrate diet reduced the population of microorganisms under the current study.

The $\mathrm{NH}_{3}-\mathrm{N}$ concentration was highest in $\mathrm{R}: \mathrm{C}$ of $0: 100$ with 0 and $4 \mathrm{mg}$ of RPM. These results may be due to a

Table 4. The effect of roughage to concentrate ratio with rain tree pod meal on bacterial population, methanogens and cellulolytic bacteria

\begin{tabular}{|c|c|c|c|c|c|c|c|}
\hline \multirow[b]{2}{*}{$\begin{array}{l}\mathrm{R}: \mathrm{C}^{1} \\
\text { ratio }\end{array}$} & \multirow[b]{2}{*}{$\begin{array}{l}\mathrm{RPM}^{2} \\
(\mathrm{mg})\end{array}$} & \multicolumn{6}{|c|}{ Real-time PCR technique, copies/ml of incubation } \\
\hline & & $\begin{array}{c}\text { Total bacteria } \\
\qquad\left(10^{9}\right)\end{array}$ & $\begin{array}{l}\text { Methanogens } \\
\qquad\left(10^{6}\right)\end{array}$ & $\begin{array}{c}\% \text { of Methanogens } \\
\text { in total bacteria } \\
\left(10^{-2}\right)\end{array}$ & $\begin{array}{l}\text { F. Succinogene } \\
\qquad\left(10^{8}\right)\end{array}$ & $\begin{array}{l}\text { R. Flavefacien } \\
\left(10^{7}\right)\end{array}$ & $\begin{array}{c}\text { R. albus } \\
\quad\left(10^{5}\right)\end{array}$ \\
\hline \multirow[t]{3}{*}{ 100:0 } & 0 & 5.3 & 1.9 & 3.6 & 1.3 & 2.9 & 2.0 \\
\hline & 8 & 5.0 & 1.8 & 3.6 & 2.3 & 2.8 & 2.7 \\
\hline & 12 & 5.9 & 1.6 & 2.7 & 2.8 & 1.1 & 2.3 \\
\hline \multirow[t]{3}{*}{$60: 40$} & 0 & 13.5 & 2.8 & 2.0 & 4.9 & 4.2 & 6.8 \\
\hline & 8 & 20.5 & 3.0 & 1.4 & 8.3 & 3.0 & 9.5 \\
\hline & 12 & 22.1 & 3.9 & 1.7 & 0.8 & 8.1 & 2.9 \\
\hline \multirow[t]{3}{*}{$20: 80$} & 0 & 34.4 & 4.3 & 1.7 & 0.7 & 4.4 & 2.1 \\
\hline & 8 & 43.6 & 4.9 & 1.1 & 0.2 & 4.2 & 2.0 \\
\hline & 12 & 33.0 & 4.2 & 1.2 & 0.6 & 4.2 & 1.3 \\
\hline SEM & & 0.23 & 0.22 & 0.10 & 0.18 & 0.11 & 0.13 \\
\hline \multicolumn{8}{|c|}{ Comparison } \\
\hline $\mathrm{R}: \mathrm{C}$ & & $* *$ & $*$ & $* *$ & $* *$ & $* *$ & $* *$ \\
\hline Leve & RPM & $*$ & 0.44 & $*$ & $* *$ & 0.15 & $*$ \\
\hline Inter & & $* *$ & 0.85 & 0.11 & $* *$ & $*$ & 0.13 \\
\hline \multicolumn{8}{|c|}{ Orthogonal polynomial } \\
\hline $\mathrm{R}: \mathrm{C}$ & & $* *$ & $*$ & * & $* *$ & $*$ & 0.46 \\
\hline $\mathrm{R}: \mathrm{C}$ & & 0.09 & 0.65 & 0.11 & 0.88 & $*$ & $*$ \\
\hline RPN & & 0.10 & 0.25 & $*$ & 0.36 & 0.18 & 0.31 \\
\hline RPN & lad) & $* *$ & 0.61 & 0.16 & $* *$ & 0.12 & $*$ \\
\hline
\end{tabular}

${ }^{1} \mathrm{R}: \mathrm{C}=$ Roughage:concentrate ratio. ${ }^{2} \mathrm{RPM}=$ Rain tree pod meal, $* \mathrm{p}<0.05, * * \mathrm{p}<0.01$. 
higher enzymatic breakdown of the dietary soluble fraction in high levels of concentrate. While $\mathrm{NH}_{3}-\mathrm{N}$ was found lowest in R:C of 100:0 and 40:60 with $12 \mathrm{mg}$ of RPM (13.9 and $14.5 \mathrm{mg} / 100 \mathrm{ml}$, respectively). This result could be due to the effects of tannins contained in RPM which protect crude protein from degradation by the formation of tanninprotein complexes in the rumen, thereby increasing metabolizable protein supply to the duodenum (MuellerHarver, 2006; Waghorn, 2008). Puchala et al. (2005) also reported that ruminal $\mathrm{NH}_{3}-\mathrm{N}$ concentrations were lower in goats fed CT-containing pasture Sericea lespedeza than crabgrass/tall fescue. However, the present level was similar to the level reported as an optimal to improve rumen ecology, digestibility and intake (Wanapat and Pimpa, 1999).

An interaction between R:C ratio and RPM level was found and which affected the total VFA concentrations. This effect was greatest in R:C of 20:80 with $8 \mathrm{mg}$ of RPM. In addition, the propionate produced was highest while the ratio of acetate to propionate and methane production was lowest in R:C of 20:80 with $8 \mathrm{mg}$ of RPM and 40:60 with $12 \mathrm{mg}$ of RPM, respectively. The high proportion of propionate was caused by a decreased methane production at the low roughage ratio due to tannins contained in RPM. The expected shift of hydrogen from the methane pathway made it available to be used to produce propionate. Effects of tannins on increased propionate and reduced acetate to propionate ratio have been found to vary with diets and applications. A similar shift in propionate production has been reported by Bhatta et al. (2009). Moreover, Chanthakhoun et al. (2011) reported that feeding Phaseolus calcaratus hay $(2.8 \% \mathrm{CT})$ at $600 \mathrm{~g} / \mathrm{hd} / \mathrm{d}$ in swamp buffalo resulted in increased production of propionate. These results indicate that a high level of concentrate can be used with RPM up to $12 \mathrm{mg}$ in in vitro studies for reducing fermentation losses and improving VFA profiles. However, the use of high levels of concentrate should be taken into consideration regarding rumen ecology and animal health problems when applied to the in vivo system.

The R:C ratio and RPM level affected the protozoal population which was lower in a R:C of 20:80 and 40:60, respectively and increased at level $12 \mathrm{mg}$ RPM. Newbold et al. (1997) found that protozoal numbers decreased when animals were fed with tannin containing foliage. Similarly with Bhatta et al. (2009) who reported that tannins suppress methanogenesis by reducing the protozoal population in vitro. Moreover, Van Soest (1982) reported that an increasing level of concentrate reduced the protozoal population. Similarly with Mackie et al. (1978) who reported that protozoal concentrations usually begin to decrease when the level of concentrate exceeds $60 \%$. On the other hand, Franzolin and Dehority (1996) reported that the average concentration of Entodinium in steers decreased when fed a $90 \%$ concentrate diet. In contrast with De Semet et al. (1992) who reported that the concentration of protozoa in ruminal contents generally increases with the addition of concentrates to roughage diets. This observation is supported by Cherdthong et al. (2010) who found that protozoal populations linearly increased with an increasing level of concentrate.

Total bacteria were highest in R:C of 20:80 with $8 \mathrm{mg}$ of RPM $\left(43.6 \times 10^{9}\right)$. While the percentage of methanogens in total bacteria was lower in R:C of 20:80 and 40:60, respectively and $12 \mathrm{mg}$ RPM. These results could be due to the effect of a high level of concentrate and tannin contained in RPM. Vinh et al. (2011) found the density of methanogens in the rumen appeared to be influenced by diet and particularly by the fiber content of the diet. Singh and Singh (1997) reported a decrease in the numbers of methanogens when cattle were fed high concentrate diet. In agreement with Poungchompu et al. (2009) who reported that a high level of concentrate diet remarkably reduced rumen methanogens. Moreover, plants containing tannins could reduce methanogens as reported by Bhatta et al. (2009), Field et al. (1989) and Animut et al. (2008).

Predominant cellulolytic bacteria in in vitro incubation were $8.3 \times 10^{8}, 8.1 \times 10^{7}$ and $9.5 \times 10^{5}$ copies $/ \mathrm{ml}$ for $F$. succinogenes, $R$. flavefaciens, and $R$. alus, respectively. Wanapat and Cherdthong (2009), Koike and Kobayashi (2001) and Russell and Rychlik (2001) reported that $F$. succinogenes was the most dominant bacteria among the three species of cellulolytic bacteria. Moreover, the level of concentrate in the diet could influence the population size or the proportion of cellulolytic bacteria numbers in the rumen. In addition, the three cellulolytic bacteria numbers examined in the present study were significantly different, responding to level of concentrate. As the results showed, the population of $F$. succinogenes was lowest in $\mathrm{R}: \mathrm{C}$ of 20:80, while $R$. flavefaciens and $R$. albus numbers quadratically decreased with an increasing level of concentrate in the diet. Similarly to Cherdthong et al. (2010) who reported that the numbers of the three cellulolytic bacteria decreased with an increasing level of concentrate. Moreover, Wora-anu et al. (2000) found that cellulolytic bacteria decreased with increased concentrate ratio in the diet. It is possible that dietary conditions reduced the numbers of cellulolytic bacteria. Furthermore, the type of feed, environmental factors such as temperature, $\mathrm{pH}$ and the existence of cations and soluble carbohydrate have been suggested as factors governing bacterial attachment (Miron et al., 2001). In the present study, the quantification of bacteria DNA demonstrated a decrease in the numbers of the three cellulolytic bacteria ( $F$. succinogenes, $R$. flavefaciens and $R$. albus) with higher levels of concentrate. 


\section{CONCLUSIONS}

Based on this study it can be concluded that the ratio of $\mathrm{R}: \mathrm{C}$ at 40:60 and RPM level at $12 \mathrm{mg}$ could improve ruminal fluid fermentation end-products in terms of increased total volatile fatty acid, propionate production and rumen microbes while acetate to propionate ratio, methane production, methanogens and protozoal population decreased. These results revealed a potential use of RPM as a supplement to improve rumen fermentation for ruminant feeding.

\section{ACKNOWLEDGEMENTS}

The authors would like to express most sincere thanks to the Tropical Feed Resources Research and Development Center (TROFREC), Thailand Research Fund (TRF) through the Royal Golden Jubilee PhD Program, Department of Animal Science, Faculty of Agriculture, Khon Kaen University, for kind financial support, experimental animals, laboratory and the use of research facilities.

\section{REFERENCES}

Animut, G., A. L. Goetsch, R. Puchala, A. K. Patra, T. Sahlu, V. H. Varel and J. Wells. 2008. Methane emission by goats consuming diets with different levels of condensed tannins from lespedeza. Anim. Feed Sci. Technol. 144:212-227.

AOAC. 1990. Official methods of analyses, 15th edn. Assoc. Offic. Anal. Chem, Arlington, VA.

Barry, T. M. 1983. The role of condensed tannins in the nutritional value of Lotus pedunculatus for sheep. 3.3Rates of body and wool growth. Br. J. Nutr. 54:211-217.

Bhatta, R., Y. Uyeno, K. Tajima, A. Takenaka, Y. Yabumoto, I. Nonaka, O. Enishi and M. Kurihara. 2009. Difference in the nature of tannins on in vitro ruminal methane and volatile fatty acid production and on methanogenic archaea and protozoal populations. J. Dairy Sci. 92:5512-5522.

Burns, R. E. 1971. Method for estimation of tannin in the grain sorghum. J. Agron. 163:511-512.

Chanthakhoun, V., M. Wanapat, C. Wachirapakorn and S. Wanapat. 2011. Effect of legume (Phaseolus calcaratus) hay supplementation on rumen microorganisms, fermentation and nutrient digestibility in swamp buffalo. Livest. Sci. : 10.1016/j.livsci.2011.02. 003.

Cherdthong, A., M. Wanapat, P. Kongmun, R. Pilajan and P. Khejornsart. 2010. Rumen fermentation, Microbial protein synthesis and cellulolytic bacterial population of swamp buffaloes as affected by roughage to concentrate ratio. J. Anim. Vet. Adv. 9:1667-1675.

De Semet, S., D. I. Demeyer and C. J. van Nevel. 1992. Effect of defaunation and hay:concentrate ratio on fermentation, fibre digestion and passage in the rumen of sheep. J. Anim. Feed Sci. Technol. 37:333-344.
Denman, S. E., N. Tomkins and C. S. McSweeney. 2005. Monitoring the effect of bromochloromethane on methanogen populations within the rumen using qPCR. In: 2nd International Symposium on Greenhouse Gases and Animal Agriculture (Ed. C. R. Soliva, J. Takahashi and M. Kreuzer). p. 112 ETH Zurich, Switzerland.

Evans, J. D. and S. A. Martin. 2000. Effects of thymol on ruminal micro-organisms. J. Current Microbiol. 41:336-340.

Field, J. A., S. Kortekaas and G. Lettinga. 1989. The tannin theory of methanogenic toxicity. Biol. Wastes 29:241-262.

Franzolin, R. and B. A. Dehority. 1996. Effect of prolonged highconcentrate feeding on ruminal protozoa concentrations. J. Anim. Sci. 74:2803-2809.

Galyean, M. 1989. Laboratory Procedures in Animal Nutrition Research. New Mexico State University.

George, W. S. and R. E. Craig. 2006. Samanea saman (rain tree). Species Profiles for Pacific Island Agroforestry.

Grainger, C., T. Clarke, M. J. Auldist, K. A. Beauchemin, S. M. McGinn, G. C. Waghorn and R. J. Eckard. 2009. Potential use of Acacia mearnsii condensed tannins to reduce methane emissions and nitrogen excretion from grazing dairy cows. Can. J. Anim. Sci. 89:241-251.

Hess, H. D., T. T. Tiemann, F. Noto, J. E. Carulla and M. Kruezer. 2006. Strategic use of tannins as means to limit methane emission from ruminant livestock. In greenhouse gases and animal agriculture: an update. In: International Congress Series No. 1293 (Ed. C. R. Soliva, J. Takahashi and M. Kreuzer). Elsevier, The Netherlands, pp. 164-167.

Johnson, K. A. and D. E. Johnson. 1995. Methane emissions from cattle. J. Anim. Sci. 73:2483-2492.

Jouany, J. P. and B. Lassalas. 1997. Study of the adaptation of the rumen ecosystem to the antimethanoginic effect of monensin measured in vivo. Reprod. Nutr. Dev. 37(Suppl. 1): S69-S70.

Koike, S. and Y. Kobayashi. 2001. Develop and use of competitive PCR assays for the rumen cellulolytic bacteria: Fibrobactor succinogenes, Ruminococcus albus and Ruminococcus flavefaciens. FEMS Microbiol. Lett. 204:361-366.

Lusin, R. and M. Wanapat. 2010. Effect of roughage to concentrate ratio and rice bran oil supplementation on rumen fermentation characteristics using in vitro gas production technique. $14^{\text {th }}$ AAAP conference at pingtung university, Taiwan, p. 353-356.

Mackie, R. I., F. M. C. Gilchrist, A. M. Robberts, P. E. Hannah and H. M. Schwartz. 1978. Microbiological and chemical changes in the rumen during the stepwise adaptation of sheep to high concentrate diets. J. Agric. Sci. 90:241.

McGinn, S. M., K. A. Beauchemin, T. Coates and D. Colombatto. 2004. Methane emissions from beef cattle: effects of monensin, sunflower oil, enzymes, yeast, and fumaric acid. J. Anim. Sci. 82:3346-3356.

Menke, K. H. and H. Steingass. 1988. Estimation of the energetic feed value obtained from chemical analysis and gas production using rumen fluid. Anim. Res. Dev. 28:7-55.

Miron, J., D. Ben-Ghedalia and M. Morrison. 2001. Invited review: Adhesion mechanisms of rumen cellulolytic bacteria. J. Dairy Sci. 84:1294-1309.

Moss, A. R., J. P. Jouany and J. Newbold. 2000. Methane production by ruminants: its contribution to global warming. J. Ann. Zootech. 49:231-253. 
Mueller-Harvey, I. 2006. Unravelling the conundrum of tannins in animal nutrition and health. J. Sci. Food Agric. 86:2010-2037.

Newbold, C. J., S. M. Hassan, J. Wang, M. E. Ortega and R. J. Wallace. 1997. Influence of foliage from African multipurpose trees on activity of rumen protozoa and bacteria. Br. J. Nutr. 78:237-249.

Ørskov, E. R. and I. McDonald. 1979. The estimation of protein degradability in the rumen from incubation measurements weighted according to rate of passage. J. Agric. Sci. 92:499503.

Patra, A. K. and J. Saxena. 2011. Exploitation of dietary tannins to improve rumen metabolism and ruminant nutrition. J. Sci. Food Agric. 91:24-37.

Poungchompu, O., M. Wanapat, C. Wachirapakorn, S. Wanapat and A. Cherdthong. 2009. Manipulation of ruminal fermentation and methane production by dietary saponins and tannins from mangosteen peel and soapberry fruit. Arch. Anim. Nutr. 63:389-400.

Puchala, R., B. R. Min, A. L. Goetsch and T. Sahlu. 2005. The effect of a condensed tannin-containing forage on methane emission by goats. J. Anim. Sci. 83:182-186.

Reed, J. D., H. Soller and A. Wodward. 1990. Fodder tree and straw diets for sheep: Intake, growth, digestibility and the effects of phenolics on nitrogen utilization. Anim. Feed Sci. Technol. 30:39-50.

Russell, J. B. and J. L. Rychlik. 2001. Factors that alter rumen microbial ecology. Science 292:1119-1122.

Samuel, M., S. Sagathewan, J. Thomus and G. Mathen. 1997. An HPLC method for estimation of volatile fatty acids of rumenfluid. Indian J. Anim. Sci. 67:805-807.

SAS, 1996. User's Guide: Statistic, Version 5. Edition. SAS. Inst, Cary, NC, USA.

Singh, K. and G. P. Singh. 1997. Effect of concentrate levels in diet of cattle on rumen microorganisms. Indian J. Anim. Sci. 64:349-350.

Slyter, L. L. 1976. Influence of acidosis on rumen function. J. Anim. Sci. 43:910-929.

Tilley, J. M. A. and R. A. Terry. 1963. A two-stage technique for the digestion of forage crops. J. Br. Grassland Soc. 18:104-111.

Van Soest, P. J. 1982. Nutritional ecology of the ruminant. O\&B Books Inc, Corvallis.
Vinh, N. T., M. Wanapat, P. Khejornsart and P. Kongmun. 2011. Studies of diversity of rumen microorganisms and fermentation in swamp buffalo fed different diets. J. Anim. Vet. Adv. 10:406-414.

Waghorn, G. C. 2008. Beneficial and detrimental effects of dietary condensed tannins for sustainable sheep and goat production progress and challenges. Anim. Feed Sci. Technol. 147:116139.

Walichnowski, Z. and S. G. Lawrence. 1982. Studies into the effects of cadmium and low $\mathrm{pH}$ upon methane production. Hydrobiologia 91-92:1573-5117.

Wanapat, M. 2000. Rumen manipulation to increase the efficient use of local feed resources and productivity of ruminants in the tropics. Asian-Aust. J. Anim. Sci. 13(Suppl.):59-67.

Wanapat, M. and A. Cherdthong. 2009. Use of real-time PCR technique in studying rumen cellulolytic bacteria population as affected by level of roughage in Swamp buffalo. Curr. Microbiol. 58:294-299.

Wanapat, M. and O. Pimpa. 1999. Effect of ruminal $\mathrm{NH}_{3}-\mathrm{N}$ levels ruminal fermentation, purine derivatives, digestibility and rice straw intake in swamp buffaloes. Asian-Aust. J. Anim. Sci. 12:904-907.

Wang, C. J., S. P. Wang and H. Zhou. 2000. Influences of flavomycin, ropadiar, and saponin on nutrient digestibility, rumen fermentation, and methane emission from sheep. J. Anim. Feed Sci. Technol. 148:157-166.

Wora-anu, S., M. Wanapat, C. Wachirapakorn and N. Nuntaso. 2000. Effects of roughage to concentrate ratio on ruminal ecology and voluntary feed intake in cattle and swamp buffaloes fed on urea- treated rice straw. Asian-Aust. J. Anim. Sci. 13(Suppl.):236-236.

Wright, A. G., A. J. Williams, B. Winder, C. T. Christophersen, S. L. Rodgers and K. D. Smith. 2004. Molecular diversity of rumen methanogens from sheep in western Australia. Appl. Environ. Microbiol. 70:1263-1270.

Yan, T., R. E. Agnew, F. J. Gordon and M. G. Porter. 2000. Prediction of methane energy output in dairy and beef cattle offered grass silage based diets. J. Livest. Prod. Sci. 64:253263.

Yu, Z. and M. Morrison. 2004. Improved extraction of PCRquality community DNA from digesta and fecal samples. Bio. Techniques. 36:808-812. 